\title{
Device Learning Development Using Cabri 3d With Problem-Solving Method Based On Oriented Critical Thinking Ability And Learning Achievements Of Junior High School Students
}

\author{
${ }^{1 \text { st }}$ Daud \\ Program of Postgraduate, \\ State University of Yogyakarta, Indonesia \\ daudsiregar502@gmail.com
}

\author{
${ }^{2 n d}$ Rusgianto Heri Santoso \\ Program of Postgraduate \\ State University of Yogyakarta, Indonesia
}

\begin{abstract}
This study aims to produce device learning development using CABRI 3D software on geometry with problem-solving method was oriented on critical thinking ability and student achievement in good quality. This material has been developed that can be used as reference materials for teachers as implementation of learning mathematics in the class. Utilization of device learning development using CABRI 3D software on geometry with problem-solving method was oriented on critical thinking ability and student achievement at junior high school which are the criteria of a valid, practical, and effective. It can be seen from the teacher's assessment against the lesson plan, is student worksheet, tests the ability of critical thinking and learning achievement test that meets the criteria specified on the practicality of this research in all aspects of the votes obtained a category very well. While the practical assessment of students meets the criteria because of the percentage of students who reach the category of well over $80 \%$. In addition, the results of observational learning wisdom show that the average percentage exceeds $75 \%$ so that the results of observation wisdom learning achieve practical criteria and activities learning can be done well.

Keywords--Device Learning Development, CABRI 3D, Problem-Solving Method, and Critical Thinking Ability
\end{abstract}

\section{INTRODUCTION}

The development of science and technology rapidly growth in use right now, learning device which used inadequate so that the knowledge of students about the technology lagged and limited learning devices used in school. Devices learning of mathematics are effective and in accordance with the subject matter has not developed as expected, and development in the field of education is very important to improve the quality and the quality of resources man. This suggests that education should be made a major priority by both Governments, the education community and Manager. Improve the quality of education endeavors to improve the quality of human resources. This gave the impetus for the Government to always trying to fix and improve the quality of education at every level of education. Technological developments in recent decades go very quickly in line with the development of technology, including computer networks. Various supporting technologies and applications have also been developed in an effort to support and facilitate the activities of human life and organization, including teaching and learning activities in the world of education. In General, the device is software to deliver information or messages from one place to another. The device used in the learning process, including teaching and learning activities.

CABRI 3D is a software that presents the mathematics and geometry can also be used in general to build learning math with ease conjures up forms that resemble the authenticity of various models. This is in accordance with the statement of (Hartatiana, Darhim and Nurlaelah, 2017) said that the CABRI 3D software for teachers can be used to solve math problems and used to teach in the learning process in the classroom. Researchers develop the device with assisted learning software CABRI 3D with the method of problem solving-oriented critical thinking ability and achievement learning math for flat-side room wake up material that can be used as one of the math learning devices that meets the criteria of a valid, practical, and effective.

\section{LITERATURE REVIEW}

\section{A. Device Learning Development Mathematics CABRI 3D}

According to Van Hiele Theory (Abdussakir, 2011) stated that in learning geometry depends on the time, materials, and learning methods are applied, which, if well laid out and integrated may improve the ability of students to think to the stage. According to Van Hiele theory, a person going through the five stages of development thinking in the fifth stage of the geometrid learning an thought Van Hiele is a stage 1 (visualization), phase 2 (analysis), phase 3 (deduction informal), stage 4 (deduction), and stage 5 (rigor). Van De Walle (2008) stated that most of the students of Junior High School lie on stage 1 (visualization) to stage 3 (informal deduction). One effective technique to motivate students to be active in learning is to strive so that students are engaging in the process of learning math more critical thinking to improve the learning achievements of students. CABRI 3D will help 
the students to visualize two dimensional and three dimensional geometric shapes. It will help them to uncover the geometric shapes easily. According to (Hartatiana, Darhim \& Nurlaelah, 2018) States that CABRI 3D software for teachers can be used to solve math problems and used to teach in the learning process in the classroom. In addition, according to (Kosa \& Karakus, 2010) CABRI 3D is potentially very useful software for learning and teaching spatial analytic geometry. Another result of the study is that CABRI 3D facilitates understanding by visualizing. According to (Subroto, 2011) states that the using of CABRI 3D software as manipulative tool in 3-dimension geometry learning can reduce misperception about 3-dimension materials. Based on the opinion of several experts above it can be concluded that the development of learning mathematics is a learning device developed using CABRI 3D software to ease the learning process in math with degrading forms that resemble the authenticity of various models, as well as helping students and teachers to overcome the difficulties and make learning geometry of three dimensions becomes more attractive.

\section{B. Problem-solving and Critical Thinking Ability}

According to NCTM (2000) Problem-solving means engaging in a task for which the solution method is not known in advance. In order to find a solution, students must draw on their knowledge, and through this process, they will often develop new mathematical understandings. According to Mayo, Donnelly, Nash \& Schwartz (Killen, 2009) define problem-solving is strategy for posing significant, contextualized, real world situation, and providing resources, guidance, and instruction to learn as they develop content knowledge and problem-solving skill's. (Firdaus et al, 2015) state that critical thinking skills should be part of students learning and schools should be responsible to develop and evaluate critical thinking skills through teaching and learning process. According to (Chukwuyenum, 2013) state that critical thinking has been one of the tools used in our daily life's to solve some problems because it involves logical reasoning, interpreting, analyzing and evaluating information to enable one take reliable and valid decisions.

\section{Quality of Product Development of learning Mathematics}

Nieveen (1999) state that we consider the three quality aspects (validity, practically, and effectiveness) also to be applicable to a much wider array of educational product. The components of the material should be based on state-ofthe art knowledge (content validity) and all components should be based on consistently linked to each other (construct validity). Teachers (and other experts) consider the materials to be usable and that it is easy for teachers and students to use the materials in a way that is largely compatible with the developers' intentions. Effective materials, consistency exists between the intended and experiential curriculum and the intended and attained curriculum.

\section{METHODS}

This research model used research and development ( $\mathrm{R} \& \mathrm{D})$. This research is focused on the development of a learning device that includes Lesson Plan and the Student Activity Sheet. The development was done by the steps of research and development methodology that was showed by Sugiyono (2008). Research methodology uses to produce a product, and to examine the effectiveness of it. The research development of this was done as an attempt to develop a device that focuses on learning achievements learning, critical thinking ability, and confidence of students by applying the methods of problem solving. Learning device that was developed in this study is the lesson plan and student worksheet. In drawing up a learning device in this study refers to the ADDIE model of development developed by the Branch (2009). This development model is composed of five main stages or phases Analysis (A), Design (D), Development (D), Implementation (I), and Evaluation (E).

ADDIE model of development was selected because it is seen a systematic and practical to implement as follow: Analysis (A); Analysis of need is used to determine the problem and the proper solution and determine the competence of students. Analysis of the characteristics of the students used to know the character of the students that will be used for field trials. Design (D); Specify the methods, reference, material, and design that will be used to design a learning device. Development (D); Develop and produce learning device and test the results of the study will be used in learning. Implementation (I); Piloted a learning device that has been developed at the school. Evaluation (E); Analyze the results that have been obtained at the time of field trials and evaluates the device learning that has been used.

\section{RESEARCH FINDINGS AND DISCUSSION}

Research has been completed at Imogiri state junior high school of grade 8 students consists of 32 students Drafting device of learning using the ADDIE model is composed of five stages of Analysis, Design, Development, Implementation, and Evaluation.

\section{A. Analysis}

Analysis of the research stage it is the needs analysis consisted of an analysis of the curriculum and an analysis of the characteristics of the students. The stage needs analysis is used to identify the issues and facts relied upon in the development of a learning device for this research. In addition, it needs analysis is used to determine the ability or competencies that need to be learned by students. Based on interviews and observations conducted with teachers of mathematics class VIII, obtained information that the teachers still use lesson plan obtained from the internet, teachers are not yet student worksheet independently making i.e. still using student worksheet by purchasing from publishers, on the purchased is student worksheet on the Publisher just present the material in a nutshell. In addition, when the learning in the classroom teachers are already using a laptop but the laptop usage hasn't been fullest due to gurus only use Microsoft office word to summarize the subject matter, the students just pay attention and note that given by the teacher. Thus causing the student will tend to be passive, not to be varied and learning to make students become quickly bored. 
Phase analysis of the characteristics of the students aiming to find out the character of the students as a whole so that the learning objectives and the learning process that will take place can be reached. Based on the results of the analysis derived from observations and interviews with teachers of mathematics class VIII in junior high school 1 Imogiri obtained Grade VIII have varying academic abilities i.e. Anyone has a high academic ability, academic ability is being, and low academic ability. This event will be based on environmental, social, and economic students.

\section{B. Design}

The design phase of this research is the researchers will compile a draft learning device and procedures of CABRI 3D. The results of the design phase in the form of draft 1 learning device developed by using problem-solving methods and procedures of CABRI 3D. As for things that are done in the design of this research on the lesson plan are as follows; 1) Compose the identity of subjects; 2) Selects core competencies, Basic Competencies and indicators; 3) determine the learning objectives; 4) compile the material to learning; 5) determine the learning methods; 6) Compile step learning; 7) specifies the engineering assessments.

This is student worksheet research that will be developed is composed of several components, namely as follows: 1) Cover is student worksheet; 2) Title is student worksheet; Learning Goal 3); 4) concept or formula discovery Activities; 5) activities apply concepts or formulas; 6) Conclusion; 7) Exercise problem. Student worksheet as developed created by using Microsoft Office Word 2013 with the letter clear and not too small so it is easy to read by students. The appearance of the student worksheet as coordinate Cartesians, line, or shape the wake room using shapes and paint application. Student worksheet as developed come with answer keys is student worksheet. CABRI 3D this procedure describes the steps in using CABRI 3D on a flat-sided room wake up material. In addition to this $3 \mathrm{D}$ CABRI procedure, there are also steps to determine the volume and surface area directly.

\section{Development}

The development phase of this research in the form of draft 2 Lesson Plan, and the procedure of Student worksheet CABRI 3D, and CABRI 3D that have been developed will be validated by experts and revision is done in accordance with the input of the validator. Components of the Draft 2 Student worksheet that has developed

1) Identity of Subjects

\section{RPP I}

\section{RENCANA PELAKSANAAN PEMBELAJARAN}

$\begin{array}{ll}\text { Satuan Pendidikan } & \text { : SMP Negeri } 1 \text { Imogiri| } \\ \text { Kelas/ Semestar } & \text { : VIII/ II (Genap) } \\ \text { Mata Pelajaran } & \text { : Matematika } \\ \text { Materi Pokok } & \text { : Bangun Ruang Sisi Datar } \\ \text { Alokasi waktu } & : 10 \times 40 \text { menit ( } 4 \text { pertemuan) }\end{array}$

Figure 1. An Identity Example of the Subjects in Lesson Plan

\section{2) Core Competencies \\ A. Kompetensi Inti}

KI 1 : Menghargai dan menghayati ajaran agama yang dianutnya.

KI 2 : Menghargai dan menghayati perilaku jujur, disiplin, tanggung jawab, peduli (toleransi, gotong royong), santun, percaya diri, dalam berinteraksi secara efektif dengan lingkungan sosial dan alam dalam jangkauan pergaulan dan keberadaannya.

KI 3 : Memahami dan menerapkan pengetahuan (faktual, konseptual, dan prosedural) berdasarkan rasa ingin tahunya tentang ilmu pengetahuan, teknologi, seni, budaya terkait fenomena dan kejadian tampak mata.

KI 4 : Mengolah, menyaji, dan menalar dalam ranah konkret (menggunakan, mengurai, merangkai, memodifikasi, dan membuat) dan ranah abstrak (menulis, membaca, menghitung, menggambar, dan mengarang) sesuai dengan yang dipelajari di sekolah dan sumber lain yang sama dalam sudut pandang/teori.

Figure 2. Examples of Core Competencies in Lesson Plan

\section{3) Basic Competence and Indicators}

Basic competence is obtained from the Permendikbud Number 68 the Year 2013 which is adapted to the material on the lesson plan to be made. While the indicators obtained from developing basic competence. Here is an example of basic competence and indicators on the lesson plan was developed.

B. Kompetensi Dasar dan Indikator
\begin{tabular}{|c|rl|}
\hline Kompetensi Dasar & \multicolumn{1}{|c|}{ Indikator } \\
\hline \begin{tabular}{|l|l|}
\hline 1.1 Menghargai dan menghayati ajaran \\
agama yang dianutnya.
\end{tabular} & 1.1 .1 & $\begin{array}{l}\text { Berdoa dengan sikap yang baik saat } \\
\text { mengawali dan mengakhiri kegiatan } \\
\text { pembelajaran. }\end{array}$ \\
& 1.1 .2 & $\begin{array}{l}\text { Mengucapkan kata bersyukur setelah } \\
\text { selesai mengerjakan tugas yang } \\
\text { diberikan guru selama kegiatan } \\
\text { pembelajaran berlangsung. }\end{array}$ \\
\hline $2.2 \begin{array}{l}\text { Menunjulkan perilaku jujur, } \\
\text { disiplin, tanggung jawab, peduli } \\
\text { (toleransi, gotong royong), santun, } \\
\text { percaya diri, dalam melakukan }\end{array}$ & 2.1 .1 & $\begin{array}{l}\text { Berkontribusi secara aktif dalam } \\
\text { kelompok. }\end{array}$ \\
\hline
\end{tabular}

Figure 3. Examples of Basic Competencies and indicators on lesson plan

\section{4) Learning Objectives}

Learning objectives are the result that will be obtained after acquiring the material students are being taught by the teacher. Here is an example of learning objectives in the lesson plan that are developed.

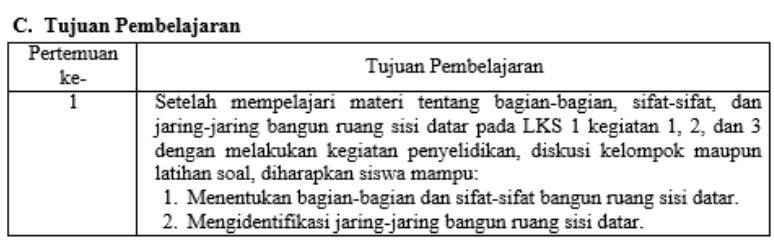

Figure 4. Examples of learning objectives in the lesson plan

\section{5) Learning Material}

D. Materi Pembelajaran

\section{Bangun Ruang Sisi Datar}

Bangun ruang sisi datar antara lain: (1) kubus, (2) balok, (3) prisma, dan (4) limas.

Berikut adalah penjelasannya.

Figure 5. Examples of Learning Material on lesson plan 6) Learning Methods 
Learning methods used in the lesson plan is a method of problem-solving. The following is an example of a learning method that is used in the lesson plan was developed.

\section{E. Model/Metode Pembelajaran}

\section{Model/Metode Pembelajaran : Problem Solving, diskusi, tanya jawab, latihan soal}

Figure 6. Examples of Learning Method on lesson plan

\section{7) The Learning Step}

The learning step on the lesson plan consists of 10 sessions, with each meeting there is steps away from the methods of problem-solving. In addition, there are learning step on the allocation of the overall time used in one of the meetings, as well as the allocation of time each step of learning. Here is an example of learning that is found in the lesson plan that are developed.

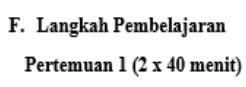

\begin{tabular}{|c|l|c|c|}
\hline Tahapan & \multicolumn{1}{|c|}{ Kegiatan Guru } & Kegiatan Siswa & $\begin{array}{c}\text { Alokasi } \\
\text { Waktu }\end{array}$ \\
\hline \multicolumn{3}{|c|}{ Kegiatan Pendahuluan } & $10^{2}$ \\
\hline Pembukaan & $\begin{array}{l}\text { \% Guru membuka pembelajaran dengan doa, } \\
\text { kemudian memberi salam. } \\
\text { \% Guru mengabsen siswa. }\end{array}$ & $\begin{array}{c}\text { \% Siswa berdoa sebelum } \\
\text { pembelajaran dimulai. }\end{array}$ & 1 \\
\hline $\begin{array}{l}\text { \% Guru menyampaikan materi, dan tujuan } \\
\text { pembelajaran yang akan dipelajari yaitu }\end{array}$ & $\begin{array}{c}\text { \% Siswa memperhatikan } \\
\text { penjelasan dari guru. }\end{array}$ &
\end{tabular}

Figure 7. Sample Learning Steps on lesson plan

\section{8) Media/Tools/Materials/Learning Resources}

Media/Tools/materials/learning resources used in the lesson plan is as follows.

G. Media/alat/bahan/sumber pembelajaran

Alat : Laptop, alat peraga menggunakan Software Cabri $3 D$ pada bangun ruang sisi datar, LCD.

\$ Bahan ajar : Matematika SMP (buku siswa) Kelas VIII, Jakarta: Kemdikbud, LKS

Sumber Belajar: 1. Contoh keadaan sehari-hari yang berhubungan dengan kubus, balok, prisma, dan limas

2. Kemdikbud. (2014). Buku guru matematika SMP/MTs kelas VIII. Jakarta: Kemdikbud

3. M. Cholik Adinawan.,\&Sugijono. (2013). Matematika SMP jilid 2B kelas VIII semester 2 berdasarkan kurikulum 2013. Jakarta: Erlangga

4. Bahan LKS.

Figure 8. Examples of Media/Tools/materials/Lesson resources

\section{9) Techniques Scoring and Assessment} Instruments

Examples of techniques scoring and assessment instrument on the lesson plan is as follows.

H. Teknik Penilaian dan Intrumen penilaian

Teknik Penilaian : Tertulis, observasi, penilaian diri, penilaian teman sejawat

Instrumen Penilaian : Soal tentang bagian-bagian dan sifat-sifat bangun ruang sisi datar (kubus, balok, prisma, dan limas), rubrik dan lembar observasi kemampuan berpikir kritis, penilaian diri, penilaian antar teman.

Gambar 9. Contoh Teknik Penilaian dan Instrumen Penilaian pada Lesson Plan
Components of the Draft 2 is student worksheet developed by using the method of problem-solving.

\section{1) Student Worksheet Cover}

There is at the beginning of the top page. The following is a sample of the title is Student Worksheet as a whole.

\section{BANGUN RUANG SISI DATAR}

\section{Lembar Kerja Siswa}

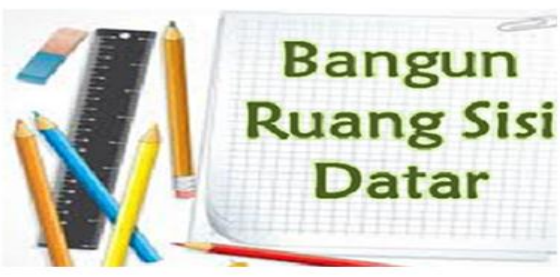

Figure 10. Example Cover is student worksheet in addition

There are student worksheet on the cover identity of students about the student's name and the number of absent students. The following is the identity of the students is Student Worksheet.

\section{Nama:}

\section{Nomor absen :}

Figure 11. Examples of Student Identity

\section{2) Title of Student Worksheet}

Student worksheet AS the title describes the material that will be covered is STUDENT WORKSHEET in. The following is a sample of the title is student worksheet.

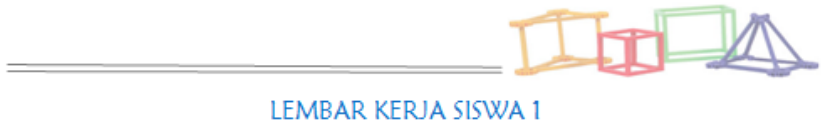

\section{BAGLAN-BAGLAN DAN SIFAT-SIFAT BANGUN RUANG SISI \\ DATAR}

Figure 12. Example Title of Student Worksheet

\section{3) Learning Objectives}

The purpose of learning about the material to be attained by the students after the study student worksheet. The following is an example of learning objectives on student worksheet.

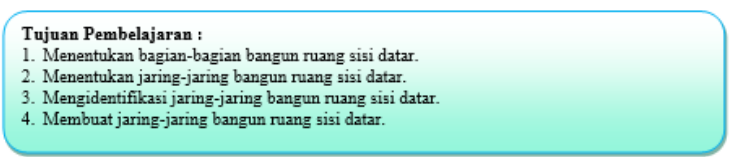

$\overline{\text { Figure 13. Examples of learning objectives on Student Worksheet }}$

4) Concept or Invention Activity Formulas

Here is an example of the invention of the concept or formula. 


\section{Masalah}

Perhatikan gambar di bawah ini.

\begin{tabular}{|l|l|}
\hline & $\begin{array}{l}\text { Rere akan membuat celengan seperti } \\
\text { gamokar di sampios dengan berbagai } \\
\text { ukuran. Bagaimana cara Bere } \\
\text { menentukan luas permukaan dari } \\
\text { selengan tersekut? }\end{array}$ \\
\hline
\end{tabular}

Figure 14. Examples of the activities of the invention of the concept or Formula

\section{5) Activities Apply Concepts or Formulas}

Here is a sample activity implements concepts or formulas student worksheet.

Kegiatan 2

Masalah

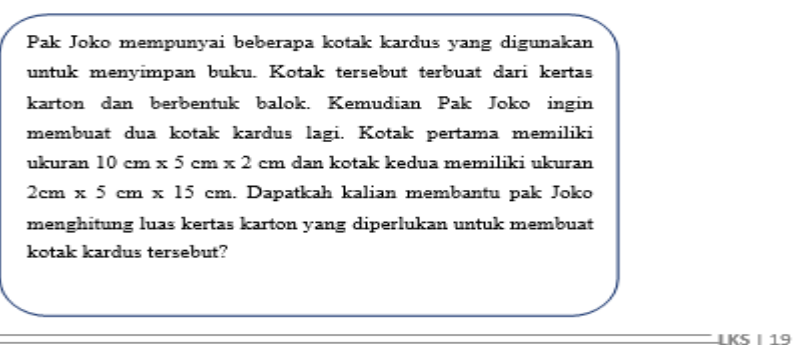

Figure 15. Sample Activity Implements concepts or Formulas on student worksheet

\section{6) Conclusion}

The following is an example of the conclusions is student worksheet.

\section{Menyimpulkan Hasil Diskusi}

Tulislah kesimpulan kalian berdasarkan data/informasi yang telah kalian peroleh

Figure 16. Examples of Activities on student worksheet

\section{7) Exercise}

Practice question on the student worksheet describes problems that are used to find out students understanding of the materials has been studied.

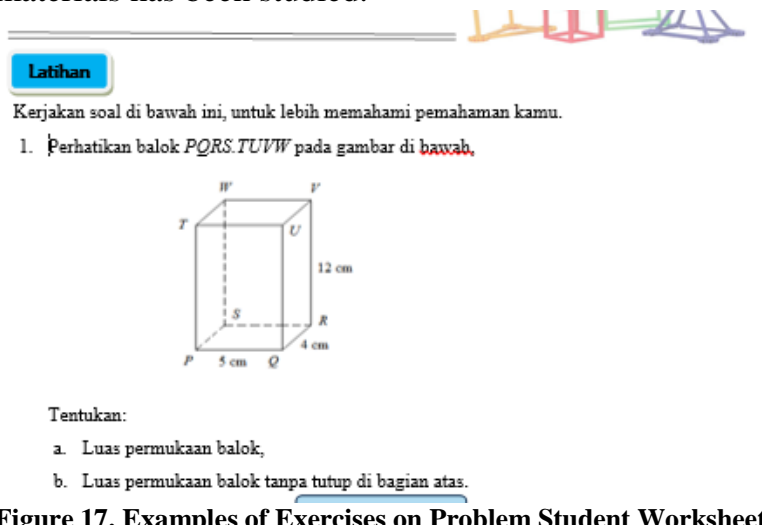

Figure 17. Examples of Exercises on Problem Student Worksheet
Components of the Draft procedure CABRI 3D researchers developed or typing about ways in using CABRI 3D software on flat-sided room wake up material. So learning will use the CABRI 3D this procedure as a guide in presenting the material.

\section{Implementation}

The implementation of which consists of the testing device of learning that has been developed in the field. Implementation stage is the stage of the testing device of learning that has been developed. In addition, at this stage of this implementation generates data in the form of a learning device trial results developed in learning mathematics with the flat side of the room to wake up material.

\section{E. Evaluation}

The evaluation Stage in this study discusses the results of the analysis of the practicability and effectiveness of the learning that has been developed, as well as the final results of the study using the method of problem-solving.

1) Data analysis data Results

Practical learning device retrieved from observation results of learning, teacher assessment results and the results of the assessment of students. Based on the data analysis the results of the assessment the teacher obtained excellent criteria on each of the aspects assessed, this indicates that the device learning and has developed practical instruments. In the data analysis, the results of the assessment of the students obtained the students who achieve at least good category there are 26 students from 32 students so that the percentage of students who achieve at least good category of $81.2 \%$. This indicates that the device learning that has been developed has reached the practical criteria. While the data observations the learning gained an average of the percentage of the whole meeting up to more than $75 \%$ i.e. $78.33 \%$, so this indicates that the device has developed practical learning. The complete data analysis the results of the assessment of the teachers can be seen in Appendix 4a pages 214, student assessment data analysis can be seen in Appendix 4b page 216, and observation data analysis of learning can be seen in Appendix 4 c page 218 .

2) Data Analysis The Effectiveness

The effectiveness of device of learning achievement test results obtained from the study and test critical thinking ability of students. Based on the results of the learning achievement test that tested retrieved 4 students who do not meet the value of KKM (minimum value of greater than and equal 75) so the completeness learning class of $87.5 \%$ and average values reach 77.8 , so it can be inferred that the learning effect in terms of learning achievement test mathematics, because completeness learn the class more than $80 \%$. Whereas in a test critical thinking ability, there is a total number of 6 students score did not reach the minimum threshold so that the overall percentage of completeness obtained from tests on critical thinking ability of $81.2 \%$, so the conclusion can be drawn that the device is effective in terms of learning tests critical thinking ability, as a percentage of the overall completeness of more than $80 \%$. 
The information of soft skills implementation by the nurses in stress management could be seen through research questionnaire as in the following:

\section{CONCLUSION}

Preparation of learning devices uses the ADDIE model is composed of five stages. The first phase, consisting of analytical needs analysis and the analysis of the characteristics of the students. The second phase, a design that consists of a design tool for learning that will be developed. The third stage, the development consists of the manufacture of the device the learning will be developed and the validation process carried out by the experts. The fourth phase consists of implementation, testing device of learning that have been developed in the field. Whereas the fifth stage, evaluation consists of the analysis of data during field trials.

Learning device developed using CABRI 3D software with the method of problem-solving have reached the criteria for "valid". This can be seen from the validation results from experts who argued that lesson plan, is student worksheet, test critical thinking ability and achievement test student learning which has been validated for use with the decent revision. In addition to the validation assessment by experts meet the category at least decent learning device that is used for the test.

Based on tests conducted using a learning device software CABRI 3D problem-solving method meets the criteria of "practical". It can be seen from the teacher's assessment against the lesson plan, is student worksheet, tests the ability of critical thinking and learning achievement test that meets the criteria specified on the practicality of this research in all aspects of the votes obtained a category very well. While the practical assessment of students meets the criteria because of the percentage of students who reach the category of well over $80 \%$. In addition, the results of observational learning wisdom show that the average percentage exceeds $75 \%$ so that the results of observation wisdom learning achieve practical criteria and activities learning can be done well.

Learning Device using CABRI 3D software with the problem-solving method meets the criteria of "effective" in terms of learning achievement tests and tests the ability of critical thinking. It can be seen from the results of the learning achievement tests and the percentage of tests the ability of critical thinking as a whole exceeds $80 \%$.

\section{References}

[1] Van de Walle, J. A. (2008). Matematika sekolah dasar dan menengah (6th ed.). (Terjemahan Suyono). Jakarta: Penerbit Erlangga. (Buku asli diterbitkan tahun 2007).

[2] Abdussakir, (2011). "Pembelajaran Geometri Sesuai Teori Van Hiele". Jurnal Kependidikan dan Keagamaan. ISSN: 1693-1499 Tahun 2010, Vol VIII Nomor 2, Januari 2010.

[3] Hartatiana, Darhim and Nurlaelah E., (2018). Improving Junior High School Students' Spatial Reasoning Ability
Through Model Eliciting Activities with Cabri 3D. International Education Studies. Vol. 11. No. 1.

[4] Kosa, T. dan Karakus, F. (2010). Using Dynamic Geometry Software Cabri 3D for Teaching Analytic Geometry. Procedia - Social and BehavioralSciences. Volume 2. Issue 2.

[5] Subroto,T. (2011).Penggunaan Software Cabri 3D Sebagai Alat Peraga Maya Dalam pembelajaran Bangun ruang di SMP Untuk Meningkatkan Kemampuan Spasial (studi kuasi-Eksperimen pada Siswa Kelas VIII SMP Talenta Bandung.Tesis Sekolah Pascasarjana Universitas Pendidikan Indonesia. Bandung.

[6] NCTM. (2000). Principles and standars for school mathematics. Reston: NCTM

[7] Killen, R. (2009). Effective teaching strategies: lessons from research and practice (5th ed). Victoria: Cengange Learning.

[8] Firdaus, Kailani.I, Md. Nor Bin Bakar, Bakry. (2015). Developing Critical Thinking Skills of Students in Mathematics Learning. Journal of Education and Learning. Vol. 9(3) pp. 226-236.

[9] Chukwuyenum, A. N. (2013). Impact of Critical thinking on Performance in Mathematics among Senior Secondary School Students in Lagos State. Journal of Research \& Method in Education (IOSR-JRME)3( 5), $18-25$.

[10] Nieveen, N. (1999). Prototyping to reach product quality'. Dalam van den Akker, J., et al. Design approaches and tools in education and training.Dordrecht: Kluwes Academic Publishers.

[11] Sugiyono, (2006). Teknik Penelitian, Yogyakarta: Pines.

[12] Branch, Robert Maribe. (2009).Instructional Design: The ADDIE Approach. New York: Springer 